\title{
LUONNOTON IHMINEN
}

$\mathrm{V}$

arhaisessa teini-iässä uhmasimme kavereiden kanssa luontoa hengailemalla minihameissa Pohjois-Suomen pakkasissa. Valittamatta kärsimme paleltumien vaivat ollaksemme vakuuttavia silloisilla muodin ja ihmissuhteiden markkinoilla. Nyt en lähtisi varttitunnin kävelymatkalle ilman lämpökerrastoa ja villasukkia, huivista ja toppatakista puhumattakaan. Sitäkö aikuistuminen ja sopusoinnun löytyminen oman ja ympäristön luontomaisuuden kanssa on?

Aikuiskasvatuksessa ja sen tutkimuksessa vallitsevat käsitykset ihmisestä ja maailmasta ovat vahvasti yhteiskunta- ja psykologiatieteellisiä. 1970-luvulla roihunneiden metodisten sotien perintö ja postmoderni eskapismi oikeuttavat alan kasvattajia ja tutkijoita edelleen pitämään luonnontieteitä ja teknisiä tieteitä pahan tiedon perikuvina. Toki humaaniin sosiaaliseen konstruktivismiin sopii silti luonnon suojeleminen ja estetisointi tai informaatio- ja viestintäteknologian oppimispsykologisesti edistyksellinen käyttö. Epäileekö kukaan meistä kuitenkaan olemuksemme orgaanista ja epäorgaanista perustaa: tähtien räjähdyksissä syntyneiden alkuaineiden kiertoa, joka rajallisen aikansa tapahtuu ihmislajin kautta?

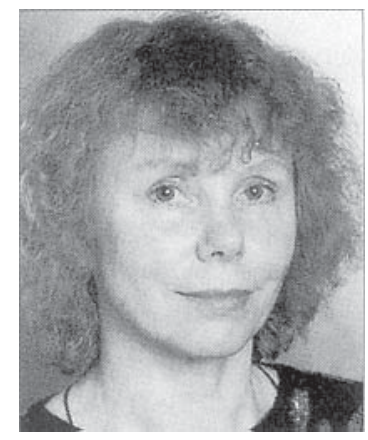

Anja Heikkinen
Ihmisen sekaantuminen inhimillisen elämän edellyttämiin planetaarisiin olosuhteisiin on lajin olemassaolon aikana jatkuvasti laajentunut ja syventynyt. Kannamme ehkä huolta intensivoituvan globaalin markkinakapitalismin ihmisyksilöille ja -ryhmille aiheuttamasta sosiaalisesta ja taloudellisesta epävarmuudesta ja valtioiden ja valtioliittojen välisten suhteiden syvenevästä militarisoitumisesta. Samalla yritämme kasvattajina ja tutkijoina pysyä mukana pudotuspelissä, jonka sääntöjä pääsemme laatimaan vain suostumuksemme kautta. Harvemmin sen sijaan pohdimme sitä, että ihmisyksilöt ja -ryhmät eivät ole ympäristöjä vain toisille ihmisyksilöille ja -ryhmille, vaan myös muulle planetaariselle elävälle ja elottomalle luonnolle. Tuohdumme bioteknologian epäkunnioittavasta suhteesta ihmisen perimään, mutta haluamme asua ja syödä halvasti ja mukavasti. Tahdomme siirtyä nopeasti paikasta toiseen, mutta huolestumme ihmiskunnan lihomisesta ja lisääntyvistä terveysongelmista. Mikään muu tuntemamme olio ei manipuloi ihmislajin tavoin lajien ja elinympäristöjen luonnotonta kehitystä. Ilman maaperän, aineiden kiertokulun, kasvien ja eläinten elämän massiivista kontrollia itseään toteuttava ja kultivoiva ihmisyys sekä politiikan ja talouden omalakisuus eivät voi todentua. Taloudellisiksi, yhteiskunnallisiksi ja kulttuurisiksi nimeämämme teot ovat väistämättä yhtä aikaa luonnollisia - tai "luonnottomia" - tekoja. 
ikuiskasvatuksen itseymmärryksessä (yleis)sivistys on ollut pyhä ja kyseenalaistamaton toiminnan lähtökohta ja tavoite. Viime vuosina toimintaa ohjeistava politiikka on entisestään korostanut yleissivistyksen keskeisyyttä: ihmisen kelpaaminen, selviytyminen ja menestys edellyttävät itseohjautuvuutta, työllistymiskykyisyyttä ja sopeutuvuutta muuntuviin informaatio- ja viestintäteknisiin toimintajärjestelmiin. Tämän todetaan edellyttävän ihmisiltä elinikäistä sosiaalisten ja käyttöliittymätaitojen ylläpitämistä. Ihmisen luontomaisuuden kiistäminen kuuluu kuitenkin edelleen humanistisen (yleis)sivistyksen ihmis- ja maailmakäsitykseen. Jos se tunnustettaisiin, sivistyksen käsite kyseenalaistuisi tai ainakin edellyttäisi uudelleentulkintaa. Elinikäisen oppimisen ja tietoyhteiskunnan tekemisen politiikalla on myös luontoon ja tekniikkaan kytkeytyvä puolensa. Ihmisen luontomaisen - fysikaalisen, kemiallisen, biologisen, geologisen, astronomisen olemuksen sekä sitä organisoivan teknologian perusteiden ymmärtäminen saattaa aikuiskasvatuksen lähtökohtana ja tavoitteena tulla aiempaa tärkeämmäksi ja osoittautua yhtä arvokkaaksi kuin ihmisen sosiaalisen ja psyykkisen elämän tulkitseminen.

Tämä teemanumero pyrkii herättämään kysymyksiä ja keskustelua, ehkä vastaväitteitäkin, aikuiskasvatuksen ja sen tutkimuksen suhteesta luontoon ja tekniikkaan. Jos elinikäisen oppimisen politiikan vaatima informaatio- ja viestintätekniikkaan sopeuttaminen vaarantaa ihmisen luontomaisen arvokkuuden, riittääkö tilanteen ymmärtämiseen vain ihmisen sosiaalisten ja psyykkisten oireiden analyysi? Ovatko luonnontieteet ihmis- ja yhteiskuntatieteellisen tiedon ominaislaadun ja hyvyyden pahin uhka? Mikä oikein on ihmisen koti - kieli vai kulttuuri, elämänkehä, maaplaneetta vai maailmankaikkeus? Isot kysymykset konkretisoituvat elämän yksityiskohdissa, kehollisessa vuorovaikutuksessa maailman kanssa. Aineeton tietotyö puuduttaa ruumiitamme, pakkanen nipistelee nenää ja saa puut paukkumaan, melu ja kiire ottavat päähän, lapsen posken pehmeys ja lämpö siirtyvät kosketuksesta mieleen, teurastetut eläimet moottoriteillä saavat vatsan kääntymään. Tähdistä olet sinä tullut, tähtiin tulet sinä jälleen palaamaan: on elämä lyhyt kuin nuorella napapaita...

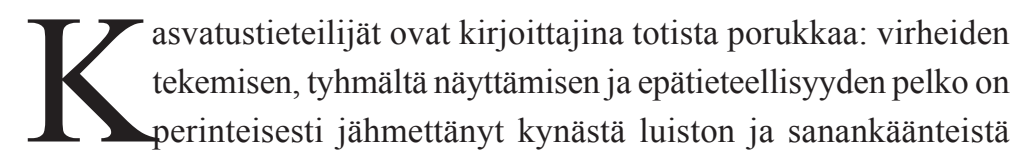
luovuuden, tekstin hurmasta ja ilosta puhumattakaan. Lehden toimitusneuvosto toivottikin viimeisimmässä kokouksessaan alkaneen vuoden totisuuden vastaisten, iloisten ja irrottelevien kirjoitusten teemavuodeksi. 